\title{
Weight-length relationship and relative condition factor of Micropterus salmoides (Lacépède, 1802), Cyprinus carpio (Linneaus, 1758) and Oreochromis niloticus (Linnaeus, 1758) caught in the Al-Massira Dam Lake
}

Sara OUAHB ${ }^{1 *}$, Meriem BOUSSEBA ${ }^{1}$, Loubna FERRAJ $^{1}$, Aziz EL MOUJTAHID ${ }^{1}$, and Mustapha HASNAOUI $^{1}$

${ }^{1}$ Environmental Engineering Team, Sciences and Techniques Faculty, Sultan Moulay Slimane University, Beni-Mellal, Morocco

*Email: sara.ouahab94@gmail.com

\begin{abstract}
The current study describes the length-weight relationships and relative condition factors (Kr) of three species during the period (September 2020- January 2021). For this purpose, 137 fish were sampled. The "size-weight"relationships thus established for each species are: Largemouth Bass: $\mathrm{Tw}=0.0055 \mathrm{Tl}^{3.2816}$, Cyprinus carpio: $\mathrm{Tw}=0.0148 \mathrm{Tl}^{2.9417}$ and Oreochromis niloticus: $\mathrm{Tw}=0.0304 \mathrm{Tl}^{2.8386}$. These results showed positive allometry for the first species (Micropterus salmoides) and a negative one for the two other species. The relative condition factor (Kr) is higher than one, which shows that these species are in good conditions at the Al-Massira dam.
\end{abstract}

Keywords: Length-weight relationships, Relative condition factor, Al-Massira.

\section{Introduction}

A length-weight relationship is an essential tool in biology, physiology, ecology and stock assessment of fishes [1]. Indeed, this relationship is a widely used approach in fisheries management, as it provides information on the status of fish stocks in an aquatic ecosystem [2,3]. In addition, the length-weight relationship is often used by researchers and nature managers to predict the weight of a fish, knowing its length, when assessing fisheries yields [4,5].

According to [6], size-weight relationship parameters provide information about fish habitat and are otherwise tools for comparison among various populations of the same species living in similar or different ecosystems $[7,8,9]$.

The condition factor provides information on the overweight status of a fish [10]. It is an instrument often used to compare the global physiological state of populations during a seasonal cycle or between basins with similar or different ecological conditions $[11,12]$. Despite the ecological and socio-economic interest of these species, studies dealing with their growth and other biological and ecological characteristics are absent in Morocco.

The objective of the present study is to investigate the length-weight relationship and condition factor of black bass, common carp and tilapia in Al-Massira Dam.

\section{Materials and methods}

\subsection{Area study}

The Al-Massira Reservoir, which was impounded in February 1979, is considered the centrepiece of the Oum Rabia watershed development plan. It is located in the province of Settat, $120 \mathrm{~km}$ southeast of Casablanca. The coordinates are $32^{\circ} 28^{\prime} 32^{\prime \prime}$ North and $7^{\circ} 32^{\prime} 15^{\prime \prime}$ West. The water resources of the Oum Rabia watershed are on the one hand of surface origin coming from three large wadis, and on the other hand, of groundwater coming from the water tables.

The climate at the reservoir level is continental, marked by a large thermal amplitude and high insolation [13]. Two factors are acting in opposite directions, precipitation and temperature condition the semi-arid climate of this region. Seasonal variations in the volume of water in the $\mathrm{Al}$ Massira Reservoir are sometimes significant; they are due to frequent and long-lasting drought episodes and result from:

- Liquid contributions from the Oum Rabia wadi,

- And restitutions (in particular extractions of the National Office of Electricity) and evaporation [13].

\subsection{Data collection}

Three species from Al-Massira Dam were selected for this study: Micropterus salmoides, Cyprinus carpio and Oreochromis niloticus. The sampling was carried out over 5 months between September 2020 and January 2021.

Measurements were made on a sample of 137 fish. Length measurements were made using an ichthyometer 
caudal fin for total length (Tl). The total weight (Tw) of the fish was measured using an electronic scale with 0.1 g precision.

\subsection{Relative growth or total weight-total length relationship}

Relative growth provides information on the overweight of fish [14] and is necessary for estimating fish biomass and the analysis of ontogenetic changes [15], and various aspects of population dynamics.

In fisheries science, this growth is used to estimate weight from size [16], weight from age [17], and to express the linear growth equation in weight growth [18]. This relationship is also used for biological and biometric studies, i.e. the study of fish conditions. This relationship also allows inter-area, inter-annual and inter-lake comparisons [19], the weight-length relationship is of power type [11]:

$$
T w=a T l^{b}
$$

With: $\mathrm{Tw}=$ total weight $(\mathrm{g}) . \mathrm{Tl}=$ total length $(\mathrm{cm}) . \mathrm{a}=$ constant. $b=$ relative growth coefficient of weight and length.

On the other hand, the values of $a$ and $b$ generally give information on the weight variations of an individual to its size. They can be compared between two or more populations living under similar or different ecological conditions.

The value of coefficient $b$ is compared statistically to $\mathrm{b}_{0}=3$. Three cases can be distinguished:

- If $b=3$, the weight increases proportionally to the length, there is an isometry.

- If $b>3$, the allometry is majoring, the fish gets bigger faster than its growth.

- If $b<3$, the allometry is minorizing, the fish grows faster than it gets bigger $[20,21,22]$.

\subsection{Relative condition factor $(\mathrm{Kr})$}

Relative condition factor $(\mathrm{Kr})$ is defined for each fish by the ratio between its observed mass and its calculated theoretical mass:

$$
K r=W / a L^{b}
$$

For each fish, the $\mathrm{Kr}$ value places it to the lengthweight curve established for the sample [11].

- If $\mathrm{Kr}>1$, the fish has a mass superior to the average mass of individuals of its size.

- If $\mathrm{Kr}<1$, its mass is smaller than the average mass.

\section{Results}

\subsection{Height-weight relationship}

individuals of black bass, common carp and tilapia, the mathematical

relations linking the total length to the total weight of the individuals were determined. In the black bass population, the minimum weight encountered is $62.3 \mathrm{~g}$ for a minimum size of $17.5 \mathrm{~cm}$. The maximum total weight is $574 \mathrm{~g}$ for a size of $34 \mathrm{~cm}$. The total lengths of the specimens vary from $14.5 \mathrm{~cm}$ to $43 \mathrm{~cm}$ in common carp with weights that vary between $48.8 \mathrm{~g}$ and $914 \mathrm{~g}$. In tilapia, the total lengths vary between $10.5 \mathrm{~cm}$ and $43 \mathrm{~cm}$, with total weights varying between $36 \mathrm{~g}$ and $1500 \mathrm{~g}$.

Table 1 shows, for the three species, the number of specimens collected, the minimum and maximum size values, the estimated $a$ and $b$ parameters as well as the correlation coefficient for total weights. Correlations between length and weight of specimens are very high, with correlation coefficients of $0.9844,0.9833$ and 0.9898 . The allometry coefficient of black bass is 3.2816 (b>3), indicating major allometry between the weight and size of this species. Thus, the black bass presents a weight growth superior to its size growth.

We find slight minorizing allometry for the other two species, namely common carp and tilapia, indicating a slower weight growth to size.

Figures (A, B, C) represent respectively the results of the variations of the relationship linking total weight and total length for the three species: black bass, common carp and tilapia.

The regression equations for the size-weight relationship for the three species are represented in Table 2. Thus, the size-weight relationship is written:

- For black bass: $\mathrm{Tw}=0.0055 \mathrm{Tl}^{3.2816}$

- For common carp: $\mathrm{Tw}=0.0148 \mathrm{Tl}^{2.9417}$

- For tilapia: $\mathrm{Tw}=0.0340 \mathrm{Tl}^{2.3687}$

As for the relative condition factors $(\mathrm{Kr})$, the results are superior to 1 for the three species: black bass, common carp and tilapia, indicate that the three species present a somatic overweight and therefore show good growth.

Table 3 presents the values of the relative condition factor for the three species.

\section{Discussion}

The study of the size-weight relationship in the three populations: black bass, common carp and tilapia in AlMassira Dam, showed a good correlation between the total weight and total size for the three species since the correlation coefficient is close to 1 . The positive and high values of the correlation coefficients obtained $\left(\mathrm{R}^{2}=\right.$ $0.9844,0.9833$, and 0.9898 ) for all the species in this study, suggest that the growth in size induces an increase in weight in the fish in the Al-Massira Dam Lake.

The value of the allometric coefficient of black bass obtained in this study $(b=3.2816>3)$, suggests that this species has a majoring allometric type growth. Thus, the black bass shows a weight growth higher than its size growth; so, he gets bigger faster than he grows. These results are similar to those found by [25] in a Reservoir in southern Brazil, [26] in Cain Lake in the USA, 
(A)

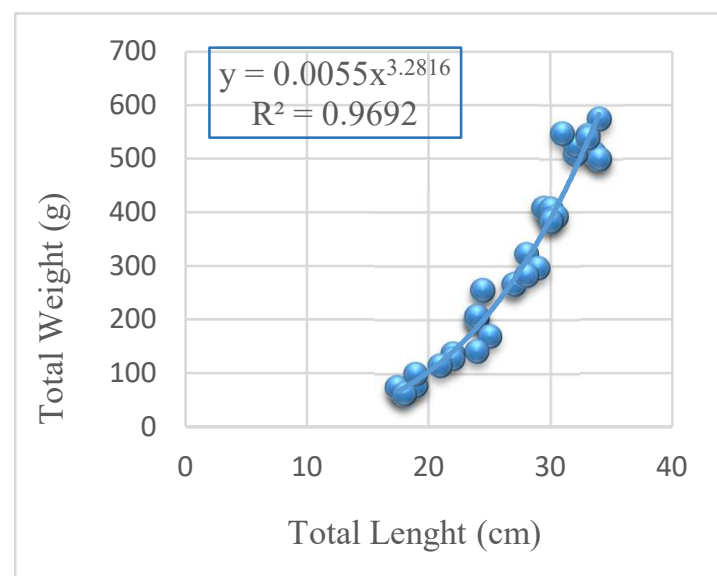

(B)

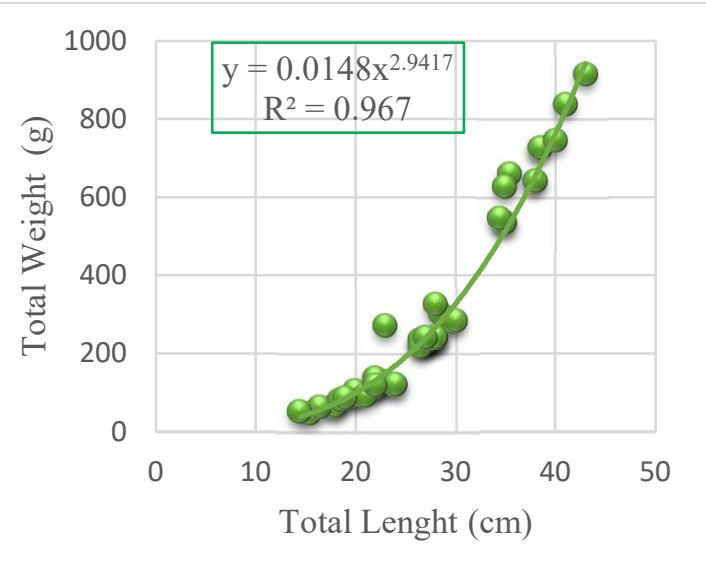

(C)

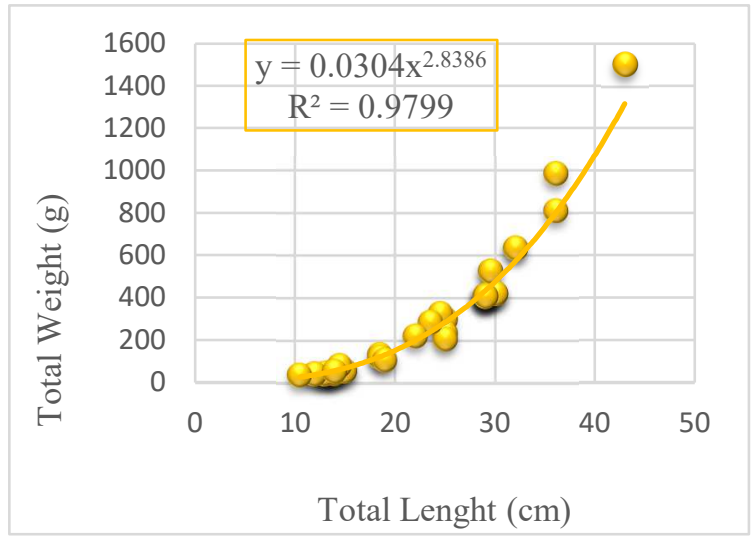

Fig.1. Size-weight relationship in black bass (A), common carp (B) and tilapia (C).

Table 1. Parameters of the weight-length relationship of the three species.

\begin{tabular}{|l|c|c|c|c|c|c|c|c|c|c|c|}
\hline Species & $\mathrm{N}$ & \multicolumn{3}{|c|}{ Total length $(\mathrm{cm})$} & \multicolumn{3}{|c|}{ Weight $(\mathrm{g})$} & $\mathrm{a}$ & $\mathrm{b}$ & $\mathrm{R}^{2}$ & $\mathrm{r}$ \\
\cline { 3 - 12 } & & Min & Max & Mean & Min & Max & Mean & & & & \\
\hline $\begin{array}{l}\text { Micropterus } \\
\text { salmoides }\end{array}$ & 46 & 17.5 & 34 & 27.45 & 62.3 & 574 & 300.02 & 0.0055 & 3.2816 & 0.9692 & 0.9844 \\
\hline $\begin{array}{l}\text { Cyprinus } \\
\text { carpio }\end{array}$ & 51 & 14.5 & 43 & 27.46 & 48.8 & 914 & 300.32 & 0.0148 & 2.9417 & 0.967 & 0.9833 \\
\hline $\begin{array}{l}\text { Oreochromis } \\
\text { niloticus }\end{array}$ & 40 & 10.5 & 43 & 22.23 & 36 & 1500 & 350.55 & 0.0304 & 2.8386 & 0.9799 & 0.9898 \\
\hline
\end{tabular}

$\mathrm{N}=$ Number of fish samples, $\mathrm{a}=$ constant, $\mathrm{b}=$ exponent, $\mathrm{R}^{2}=$ determination coefficient, $\mathrm{r}=$ regression coefficient, max $=$ maximum, $\min =$ minimum.

Table 2. Regression equations and growth type in the three species.

\begin{tabular}{|l|c|c|c|}
\hline \multicolumn{1}{|c|}{ Species } & $\mathrm{B}$ & Growth Pattern & Equation de regression \\
\hline Micropterus salmoides & 3.2816 & $\mathrm{~A}+$ & $\mathrm{Tw}=0.0055 \mathrm{Tl}^{3.2816}$ \\
\hline Cyprinus carpio & 2.9417 & $\mathrm{~A}-$ & $\mathrm{Tw}=0.0148 \mathrm{Tl}^{2.9417}$ \\
\hline Oreochromis niloticus & 2.8386 & $\mathrm{~A}-$ & $\mathrm{Tw}=0.0304 \mathrm{Tl}^{2.8386}$ \\
\hline
\end{tabular}

A- = negative allometry, $\mathrm{A}+=$ positive allometry.

Table 3. Relative condition factor $(\mathrm{Kr})$ in the three species.

\begin{tabular}{|l|c|c|c|}
\hline \multirow{2}{*}{ Species } & \multicolumn{3}{|c|}{ Relative condition factor (Kr) } \\
\cline { 2 - 4 } & Min & Max & Mean \\
\hline Micropterus salmoides & 0.757 & 1.278 & 1.005 \\
\hline Cyprinus carpio & 0.717 & 1.806 & 1.078 \\
\hline Oreochromis niloticus & 0.729 & 1.495 & 1.008 \\
\hline
\end{tabular}


Table 4. Comparison of the parameters of the size-weight relationship of the three species with the results of other authors

\begin{tabular}{|c|c|c|c|c|c|}
\hline Species & Authors and Year & Study region & $\mathrm{A}$ & $\mathrm{B}$ & $\mathrm{R}^{2}$ \\
\hline \multirow{6}{*}{$\begin{array}{l}\text { Micropterus } \\
\text { salmoides }\end{array}$} & $\begin{array}{l}\text { Schulz and Leal } \\
\text { (2005) }\end{array}$ & $\begin{array}{l}\text { Brazil (Reservoir in } \\
\text { southern Brazil) }\end{array}$ & $2 . \overline{32}$ & 3.28 & 0.992 \\
\hline & $\begin{array}{l}\text { Inman and al } \\
(2015)\end{array}$ & USA (Cain Lake) & $\begin{array}{c}- \\
4.9409 \\
\end{array}$ & 3.1349 & \\
\hline & $\begin{array}{l}\text { Taylor and Weyl } \\
\text { (2017) }\end{array}$ & $\begin{array}{r}\text { South Africa } \\
\text { (Wriggleswade) }\end{array}$ & & 3.033 & 0.989 \\
\hline & $\begin{array}{l}\text { Taylor and Weyl } \\
\text { (2017) }\end{array}$ & $\begin{array}{l}\text { South Africa } \\
\text { (Mankazana) }\end{array}$ & & 3.296 & \\
\hline & $\begin{array}{l}\text { Keyombe et al. } \\
(2020)\end{array}$ & Kenya (Lake Naivasha) & $\begin{array}{l}0.00 \\
82\end{array}$ & 3.1459 & 0.9748 \\
\hline & Present study & $\begin{array}{l}\text { Morocco (Al-Massira } \\
\text { Dam) }\end{array}$ & $\begin{array}{l}0.00 \\
55\end{array}$ & 3.2816 & 0.9692 \\
\hline \multirow{6}{*}{$\begin{array}{l}\text { Cyprinus } \\
\text { carpio }\end{array}$} & Carlander (1969) & Japan (Shioda Plain) & $\begin{array}{l}0.00 \\
60\end{array}$ & 3.210 & \\
\hline & $\begin{array}{l}\text { Kirankaya and } \\
\text { Ekmekçi (2004) }\end{array}$ & $\begin{array}{l}\text { Turkey (Gelingülü Dam } \\
\text { Lake) }\end{array}$ & $\begin{array}{l}0.02 \\
2\end{array}$ & 3.023 & 0.956 \\
\hline & $\begin{array}{l}\text { Tarkan and al, } \\
(2006)\end{array}$ & Turkey (Lake Iznik) & $\begin{array}{l}0.02 \\
50\end{array}$ & 2.830 & \\
\hline & $\begin{array}{l}\text { Karatas and al. } \\
\text { (2007) }\end{array}$ & $\begin{array}{l}\text { Turkey (Almus Dam } \\
\text { Lake) }\end{array}$ & $\begin{array}{l}0.00 \\
5\end{array}$ & 3.319 & 0.944 \\
\hline & $\begin{array}{l}\text { Moradinasab and } \\
\text { al. (2012) }\end{array}$ & Iran (Caspian Sea) & $\begin{array}{l}0.03 \\
14\end{array}$ & 2.8449 & 0.93 \\
\hline & Present study & $\begin{array}{l}\text { Morocco (Al-Massira } \\
\text { Dam) }\end{array}$ & $\begin{array}{l}0.01 \\
48\end{array}$ & 2.9417 & 0.967 \\
\hline \multirow{6}{*}{$\begin{array}{l}\text { Oreochromis } \\
\text { niloticus }\end{array}$} & $\begin{array}{l}\text { Gómez-Márquez } \\
\text { and al. (2008) }\end{array}$ & $\begin{array}{l}\text { Mexico (Lake } \\
\text { Coatetelco) }\end{array}$ & $\begin{array}{l}0.12 \\
07\end{array}$ & 2.469 & 0.8114 \\
\hline & $\begin{array}{l}\text { Waithaka and al, } \\
\text { (2020) }\end{array}$ & Kenya (Lake Naivasha) & $\begin{array}{l}0.03 \\
1\end{array}$ & 2.86 & 0.92 \\
\hline & Shija (2020) & Ethiopia (Lake Chamo) & $\begin{array}{l}0.01 \\
02 \\
\end{array}$ & 3.1779 & 0.972 \\
\hline & $\begin{array}{l}\text { Yem and al. } \\
(2020)\end{array}$ & Nigeria (Wase Dam) & 0.10 & 1.52 & 0.81 \\
\hline & $\begin{array}{l}\text { Mohamed and } \\
\text { Salman (2021) }\end{array}$ & Iraq (Garmat Ali River) & $\begin{array}{l}0.01 \\
2 \\
\end{array}$ & 3.109 & 0.969 \\
\hline & Present study & $\begin{array}{l}\text { Morocco (Al-Massira } \\
\text { Dam) }\end{array}$ & $\begin{array}{l}0.03 \\
04\end{array}$ & 2.8386 & 0.9799 \\
\hline
\end{tabular}

[27] in Lake Mankazana in South Africa and [28] in Lake Naivasha in Kenya. Only the results obtained by [27] at Lake Wriggleswade in South Africa are different.

For common carp, the value of $b$ is less than $3(b=$ 2.9417) and shows that the growth of common carp has a negative allometric type characterized by growth in length more than growth in weight. Negative allometry was highlighted for the same species by [29] in Turkey (Lake Iznik) and [30] in Iran (Caspian Sea). On the other hand, [31] revealed that the allometric coefficient of common carp indicates positive allometric growth in Korea. [32] observed such growth for the same species in Turkey (Almus Dam Lake). While, [33] found isometric growth in the same species in Gelingülü Dam Lake in Turkey (Table 4).

The value of the tilapia allometric coefficient also suggests a negative allometric growth $(b=2.8386<3)$. [34] found a similar result in Lake Coatetelco, the same results were suggested by [35] in Lake Naivasha and [36] in Wase Dam. However, [37] obtained in Lake Chamo, a major growth of this species. The same result was obtained by [38] in Garmat Ali River.

According to the previous results, a variation of the allometry coefficient (b) is observed for the three species.
These variations can be linked to several factors. Indeed, the literature mentions that the allometry coefficient can be influenced by sex, growth phase, stomach contents, level of gonad development [39] and environmental conditions [40] (Table 4).

The values of the relative condition factors $(\mathrm{Kr})$ of all the studied species are higher than 1, which suggests that these species were in good conditions in their biotope (Al-Massira Dam).

\section{Conclusion}

The present study, which provides information on the length-weight and condition coefficients of three of the most abundant fish species in the Al-Massira Dam, is one of the few studies dealing with the biology of Moroccan freshwater fish. It mainly provides an important data base for researchers and nature managers in elaborating management and conservation measures for the fish populations of the Al-Massira Dam. The condition coefficient is always higher than 1 , which indicates the well-being of the fish within their biotope. 


\section{References}

[1] L. Bolognini, F. Domenichetti, F. Grati, P. Polidori, G. Scarcella, and G. Fabi, Weight-Length Relationships for 20 Fish Species in the Adriatic Sea, Turk. J. Fish. Aquat. Sci., vol. 13, (2013).

[2] T. B. Bagenal and A. T. Tesch, Conditions and growth patterns in fresh water habitats, Blackwell Sci. Publ. Oxf. Retrieved, vol. 18, pp. 09-16, (1978).

[3] M. Y. Hossain, Z. F. Ahmed,P. M. Leunda,S. Jasmine, J. Oscoz, R. Miranda and J. Ohtomi, Condition, length-weight and length-length relationships of the Asian striped catfish Mystus vittatus (Bloch, 1794) (Siluriformes: Bagridae) in the Mathabhanga River, southwestern Bangladesh, J. Appl. Ichthyol., vol. 22, no. 4, pp. 304-307, (2006).

[4] R. Froese, Cube law, condition factor and weight-length relationships: history, meta-analysis and recommendations, J. Appl. Ichthyol., vol. 22, no. 4, pp. 241-253, (2006).

[5] R. Froese, J. T. Thorson, and R. B. Reyes, A Bayesian approach for estimating length-weight relationships in fishes, J. Appl. Ichthyol., vol. 30, no. 1, pp. 78-85, (2014).

[6] K. Lorenzen, Population dynamics and management, in Tilapias: Biology and Exploitation, $\mathrm{M}$. C. M. Beveridge and B. J. McAndrew, Eds. Kluwer Academic Publishers, Dordrecht. pp. 163-225. (2000).

[7] K. I. Stergiou and D. K. Moutopoulos, A review of length-weight relationships of fishes from Greek marine waters, Naga, The ICLARM Quarterly, vol. 24, no $.1 \& 2)$ (2001).

[8] J. Thomas, S. Venu, and B. M. Kurup, Lengthweight relationship of some deep-sea fish inhabiting the continental slope beyond $250 \mathrm{~m}$ depth along the West Coast of India, NAGA WorldFish Cent. Q., vol. 26, no. 2, pp. 17-21, (2003).

[9] N. Odat, Length-weight relationship of fishes from coral reefs along the coastline of Jordan (Gulf of Aqaba), Naga, vol. 26, no. 1, pp. 9-10, (2003).

[10] D. Paugy, C. Lévêque, and O. Otero, The inland water fishes of Africa: diversity, ecology and human use. IRD éditions, (2018).

[11] E. D. Le Cren, The length-weight relationship and seasonal cycle in gonad weight and condition in the perch (Perca fluviatilis), J. Anim. Ecol., pp. 201-219, (1951).

[12] M. D. L. a. P. Lizama and A. M. Ambrósio, Condition factor in nine species of fish of the Characidae family in the upper Paraná River floodplain, Brazil, Braz. J. Biol., vol. 62, no. 1, pp. 113-124,(2002).

[13] M. Malki, Etude de la communauté phytoplanctonique et des caractéristiques physicochimiques des eaux du lac Réservoir Al Massira, Thèse de Doctorat, Univ. Hassan II, Casablanca : 168 p, (1994).

[14] H. Richter, C. Luckstadt, U. Focken, and K. Becker, An improved procedure to assess fish condition on the basis of length-weight relationships, Arch. Fish. Mar. Res., vol. 48, no. 3, pp. 255-264, (2000).

[15] P. Safran, Theoretical analysis of the weightlength relationship in fish juveniles, Mar. Biol., vol. 112, no. 4, pp. 545-551, (1992).

[16] J. E. Beyer, On length-weight relationships. Part II: Computing mean weights from length statistics, Fishbyte, vol. 9, no. 2, pp. 50-54, (1991).
[17] G. Petrakis and K. I. Stergiou, Weight-length relationships for 33 fish species in Greek waters, Fish. Res., vol. 21, no. 3-4, pp. 465-469, (1995).

[18] D. Pauly, Fishbyte Section Editorial Naga ,Manila Phillipines ICLARM Q., pp. 16-22 (1993).

[19] P. Mergen, Distribution spatio-temporelle des communautés ichtyologiques dans les lacs de barrage de Nisramont (Belgique) et d'Esch-sur-Sßre (Grand-Duché $\mathrm{du}$ Luxembourg). Presses universitaires de Namur, (2002).

[20] S. Gerster, A. Krämer, and E. Staub, Bewirtschaftung des Barsches im Bodensee. Bundesamt für Umwelt, Wald und Landschaft, (1995).

[21] J.L. Noiset, Dynamique de populations et exploitation de trois Cichlidae (Teleostei) de la zone inondable de la rivière San Pedro (Tabasco, Mexique). Presses universitaires de Namur, (1994).

[22] J. Didier, Essais d'évaluation de la dynamique de population de deux espèces abondantes en Haute-Meuse: le gardon (Rutilus rutilus) et de la perche (Perca fluviatilis). Croissance, taux de mortalité, taux d'exploitation, Mémoire de Licence en Sciences biologiques, Facultés universitaires Notre-Dame de la Paix à Namur, 68 p, (1990).

[23] J. C. Micha, Etude des populations piscicoles de l'Ubangui et tentatives de sélection et d'adaptation de quelques espèces à l'étang de pisciculture, Nogent-surMarne : GERDAT-CTFT, 110 p. (1973).

[24] W. E. Ricker, Calcul et interprétation des statistiques biologiques des populations de poissons, Bull. Fish. Res. Board Can. 191F, 409 p, (1980).

[25] U. H. Schulz and M. E. Leal, Growth and mortality of black bass, Micropterus salmoides (Pisces, Centrachidae; Lacapède, 1802) in a reservoir in southern Brazil, Braz. J. Biol., vol. 65, no. 2, pp. 363-369, (2005).

[26] C. R. Inman, R. C. Dewey, and P. P. Durocher, Growth comparisons and catchability of three largemouth bass strains, Fisheries, vol. 2, no. 5, pp. 20-25, (1977).

[27] G. C. Taylor and O. L. F. Weyl, Age, growth and reproduction of non-native largemouth bass Micropterus salmoides (Lacépède, 1802) populations in two temperate African impoundments, J. Appl. Ichthyol., vol. 33, no. 4, pp. 767-775, (2017).

[28] J. L. Keyombe, K. Obiero, E. Waithaka, N. Outa, O. Donde, and D. Kyule, Understanding selected growth aspects in Redbelly Tilapia, Coptodon zilli (Gervais) and Largemouth Bass, Micropterus salmoides (Lacepède) in Lake Naivasha, Kenya; Fisheries Management Perspective, Pan Afr. Sci. J., vol. 1, no. 01, (2020)

[29] A. S. Tarkan, Ö. Gaygusuz, H. Acıpınar, Ç. Gürsoy, and M. Özuluğ, Length-weight relationship of fishes from the Marmara region (NW-Turkey), J. Appl. Ichthyol., vol. 22, no. 4, pp. 271-273, (2006).

[30] A. Moradinasab, H. Raeisi, S. Paighambari, R. Ghorbani, and Z. Bibak, Length-Weight relationships, Relative condition factor and Relative weight of three fish species from beach seine fishing grounds Iranian coastal waters of Caspian Sea, J. Appl. Sci. Res., vol. 1, pp. 36-40, Jan. (2012).

[31] K. D. Carlander, Handbook of Freshwater Fishery Biology, Life History Data on Freshwater Fishes of the United States and Canada, Exclusive of the Perciformes, Iowa State Univ. Press, Ames, Iowa, vol. 1, $752 \mathrm{pp},(1969)$. 
(Cyprinus carpio Linneaus, 1758) Population in Almus Dam Lake (Tokat- Turkey), J. appl. biol. Sci., 1:81-85, (2007).

[33] Ş. G. KIRANKAYA and F. G. EKMEKÇİ, Growth properties of mirror carp (Cyprinus carpio L., 1758) introduced into Gelingüllü Dam Lake, Turk. J. Vet. Anim. Sci., vol. 28, no. 6, pp. 1057-1064, (2005).

[34] J. L. Gómez-Márquez, B. Peña-Mendoza, I. H. Salgado-Ugarte, and J. L. Arredondo-Figueroa, Age and growth of the tilapia, Oreochromis niloticus (Perciformes: Cichlidae) from a tropical shallow lake in Mexico, Rev. Biol. Trop., vol. 56, no. 2, pp. 875-884, (2008).

[35] E. Waithaka, E. Yongo, N. Outa, and E. Mutethya, Population Biology of Nile tilapia (Oreochromis niloticus ) in Lake Naivasha, Kenya, Lakes Reserv. Res. Manag., vol. 25, no. 2, pp. 244-249, (2020).

[36] I. Y. Yem, N. O. Bankole, R. Umar, A. Ibrahim, and S. J. Ewutanure, Food habit and growth pattern of Nile Tilapia Oreochromis niloticus in Wase Dam, Nigeria, Int .J. Fish. Aqua. Stud., 8(4): 257-260 (2020).

[37] B. S. Shija, Length-Weight Relationship and Fulton's Condition Factor of the Nile Tilapia (Oreochromis niloticus L., 1758) in Lake Chamo, Ethiopia, J. Agric. Environ. Sci., vol. 5, no. 2, (2020).

[38] A.-R. M. Mohamed and A. N. Salman, Comparison of Length and Weight Characteristics of $\mathrm{O}$. niloticus and O. aureus from Garmat Ali River, Iraq, Asian J. Fish. Aquat. Res., pp. 39-51, (2021). length-weight and length-length relationships of the Asian striped catfish Mystus vittatus (Bloch, 1794) (Siluriformes: Bagridae) in the Mathabhanga River, southwestern Bangladesh, J. Appl. Ichthyol., vol. 22, no. 4, pp. 304-307, (2006).

[40] F. Baby, J. Tharian, K. M. Abraham, M. R. Ramprasanth, A. Ali, and R. Raghavan, Length-weight relationship and condition factor of an endemic stone sucker, Garra gotyla stenorhynchus (Jerdon, 1849) from two opposite flowing rivers in southern Western Ghats, J. Threat. Taxa, vol. 3, no. 6, pp. 1851-1855, (2011). 